\title{
COMMUNICATIONS
}

\section{Pola Komunikasi Feminisme Dalam Video Najwa Shihab dan Agnes Monica}

1* Muhammad Munir, ${ }^{2}$ Dimas Ayu Pamukir

${ }^{1}$ STAI Al-Azhar Menganti, ${ }^{2}$ UIN Sunan Ampel Surabaya

1*muniralafasy39@gmail.com, dimasayu79@gmail.com

\section{ARTICLE INFO}

Received on 7 Desember 2020

Received in revised from 9 January 2021

Accepted 31January 2021

Published on 31 January 2021

Keywords: (3-5 words)

Communication Pattern;

Femenism;

Patriarchy

How to cite this article: Munir, Muhammad dan Dimas Ayu Pamukir. (2021). Pola Komunikasi Feminisme Dalam Video Najwa Shihab dan Agnes Monica. Communications 3(1)87-107

\section{ABSTRACT}

This study aims to explain the communication patterns of femenism use content analysis. Data collection methods with coding on content narrative video of Najwa Shihab and Agnes Monica. Reseacrh result explain considering that the video tells the Pattern of Communication of Feminism and Patriarchy in the world of work, the Culture of Patriarchy in Indonesia, the Role of Femenism, the Suppression of femenism, the Communication Pattern of Fellow femenism. 


\section{PENDAHULUAN}

Perempuan telah banyak mendapatkan diskriminasi baik dari bidang ekonomi, politik, sosial, SARA, perempuan hanya bisa dianggap bisa membimbing rumah tangga saja. Perempuan masih belum mendapatkan sebuah kesetaraan sebagai perempuan, energi dan beban kerja seorang perempuan belum mendapatkan penghargaan dan kehomatan, justru mendapatkan diskriminasi kepada perempuan secara terus menerus. Dengan kajadian tersebut seluruh dunia bersepakat bahwa sebagian besar wanita masih terjaring miskin, karena masalah kesetaraan dan kelayakan dalam dunia kerja khususnya. (T. M. Umar, 2005, p. 54)

Salah satu faktornya biasanya karena terjadinya sebuah kasus bullying dan penindasan pada perempuan. Dahulu sering terjadi sebuah kekerasan yang menimpa perempuan baik dirumah, di sekolah, jalanan, pasar dan tempat-tempat lainnya, akibatnya para perempuan masih belum bisa untuk show on public karena dengan keterbatasannya. Wanita lebih menggunakan sebuah perasaan untuk menilai seseorang. Kasus bullying sampai kapanpun akan tetap terjadi, seperti contoh kasus yang terjadi pada Lucinta Luna semua orang masih sering membully tentang transgender yang dia lakukan, akhirnya dia juga mengalami sebuah depresi yang mengharuskan untuk meminum pil penenang, hal ini contoh kecil dari kasus bullying gander. Kasus bullying sudah semakin menyebar keseluruh nusantara bahkan seluruh dunia. Adannya teknologi sudah berubah bentuk kekerasan yang terjadi dimedia sosial. Menurut data yang dikeluarkan oleh Persatuan Bangsa Bangsa kurang lebih 95\% telah terjadi sebuah arogensi dan perlakuan yang agresif, cat calling, body shaming dan lain-lain. (Tong, 1997, p. 45)

Fenomena feminisme yang terjadi di Indonesia berupa sebuah kejahatan dan pelecehan pada perempuan yang dikaitkan dengan permasalahan hukum, ekonomi dan ketenaga kerjaan, politik, SARA, bahkan bisa saja terjadi di sekolah. Fenomena tersebut sering ditemukan dimedia sosial seperti kasus yang terjadi saat ini ialah penganiayaan teman disalah satu sekolah yang menganiaya teman perempuan. Ada tiga anggapan tentang faktor kekerasan yang terjadi pada perempuan. Pertama, kekerasan seksual patriarki itu adalah sifat lahiriyah yang tidak bisa dipungkiri (given), sehingga bukan merupakan sebuah tanggung jawab seorang laki-laki ketika 
COMMUNICATIONS Vol..3(1) 2021, p.87-107

e-ISSN: 2684-8392 |https://doi.org/10.21009/Communications3.1.5

melalukan kekerasan. Kedua, penerima bully-an dan penganiayaa berada dalam keadaan fisik yang kurang semangat atau lemah, atau sering kali perempuan disalahkan. Ketiga, hukum seksualitas merupakan hukum kememilikan dimana perempuan tidak bisa menuntut haknya, bahkan perempuan sampai lupa bahwa hal ini adalah sebuah integritas. (T. M. Umar, 2005, p. 57)

Feminisme merupakan sebuah cara untuk memposisikan perempuan sebagai makhaluk sosial yang diperlakukan sama dengan laki-laki. Menurut pemikir sosial saat ini yang berlandaskan dalam kata "feminisme" menafsirkan perempuan sebagai pusat interaksi sosial: pertama, perempuan sebuah "objek" penelitian, pengalaman dan keadaan perempuan yang terjadi pada masyarakat dan lingkungan sosial; kedua, perempuan sebuah "subjek" artinya framing massa tentang perempuan; ketiga, teori feminis mencoba mengkritisi dengan memberikan pembelaan kepada perempuan yang bisa mengubah lingkungannya menjadi lebih baik. (Ismail, 2003, p. 65)

Feminisme datang sebagai respon dari perempuan yang tertindas atau dilecehkan. Tujuan terciptanya feminisme membuka berbagai cara untuk bisa memberikan kebebasan kepada perempuan dari patriarki. Salah satunya ialah memberikan kesetaraan kepada perempuan di dalam dunia kerja. Dahulu seorang perempuan sering mendapatkan diskriminasi saat terjun pada sebuah pekerjaan, karena pada saat itu perempuan dianggap sebagai orang yang lemah dan tidak bisa menyelesaikan pekerjaan seperti layaknya seorang laki-laki. Masalah tersebut berakibat kepada perbedaan gaji secara kasat mata feminis mendapatkan gaji yang lebih kecil. Hal ini bukan satu-satunya masalah yang terjadi pada perempuan diluar hal tersebut masih sering terjadi. Seperti yang terjadi kepada seorang karyawan perempuan di Amerika Serikat, bernama Nicole Lee Hallberg, memberikan contoh kepada perempuan bahwa masih mendapatkan ketidakadilan ketika berbeda di kantor walaupun pekerjaannya yang dikerjakannya tidak jauh beda dengan lakilaki.(Jamhari, 2003, p. 67)

Patriarki ialah cara interaksi laki-laki dalam sosial yang mengidentitaskan laki-laki sebagai seorang actor dari berbagai bidang seperti pemimpin dalam politik, lembaga kekuasaan, dan pemegang saham-saham properti. Pada lingkup keluarga, laki-laki adalah seorang pemimpin dalam keluarga tersebut, seperti pemimpin pada istri, anak- 
anak dan kepemilikan dari kekayaannya. Budaya pada patriarkal juga melihat pada garis keturunan dari seorang laki-laki, dalam artinya semua harta benda jatuh lebih banyak pada laki-laki. Secara tidak langsung hal ini seperti monomersatukan laki-laki daripada perembuan. (Ismail, 2003, p. 11)

Dalam lingkup sosial menganggap bahwa laki-laki mempunyai keistimewaan dari perempuan. Pengakuan ini tidak hanya diakui secara personal saja, melainkan semua masyarakat telah mengetahui bahwa laki-laki lebih bisa memegang kekuasanya dari pada perempuan, salah satu contoh bahwa patriarki ini bisa memberikan partisipasi pada sosial, politik, ekonomi, pendidikan, hukum dan keagamaan. Dalam konteks sosial budaya patriarki ialah sebuah bias dari segala kekerasan dan diskriminasi pada perempuan. Berdasarkan sebuah hak yang istimewa terdapat pada personal diri lakilaki, dengan sifat tersebut muncul sebuah rasa angkuh yang tertanam dalam diri lakilaki dan menganggap yang menarik dari wanita itu hanyalah body shaming.

Sejarah patriarki bisa dilihat dari berbagai implementasi sosial dan SARA yang beraneka ragam atau multikultural. Bahkan tidak secara mudah tercantum pada ranah hukum dalam pemerintahan, secara umum masyarakat multikutural dan masyarakat erupsi dengan teknologi yang mendomenasikan sifat dan sikap patriarki. (Ihromi, Irianto, \& Luhulima, 2000, p. 3)

Sistem patriarki mempengaruhi kegiatan masyarakat yang memberikan dampak kecondongan pada laki-laki dan tidak adil karena budaya patriarki ini di dominan pola komunikasi yang tertanam setiap hari pada interaksi laki-laki. Peran laki-laki sangat menguntungkan masyarakat karena bisa melindungi bahkan bisa mengontrol masyarakat, sedangkan peran perempuan terkesan lemah dan tidak memberikan kemampuan apa-apa bahkan tidak memilik hak dalam masyarakat, secara sosial, politik, ekonomi bahkan budaya pernikahan masih terkesan rendah bahkan berada di bawah kapasitas. (Dzuhayatin, Rachman, \& Umar, 2002, p. 5)

Budaya penganggapan bahwa wanita itu tidak seperti laki-laki itu adalah budaya konstruksi saja yang tertuang dan diberlakukan kepada anak muda sekarang dari nenek moyang terdahulu, karena pada hakikatnya didalam tubuh manusia itu terdapat dua sifat gander. Sifat gander feminisme dan sifat gander patriarki. Dua sifat tersebut 
COMMUNICATIONS Vol..3(1) 2021, p.87-107

e-ISSN: 2684-8392 |https://doi.org/10.21009/Communications3.1.5

melekat pada setiap insan yang di domenasi pada sifat gander yang sesungguhnya, akan tetapi di sisi lain akan muncul sifat tersebut dikala terjadi darurat, untuk melindungi dan membentengi dirinya masing-masing. (Karim, Nahdiyyin, \& Maryam, 2007, p. 59)

Datangnya tradisi patriarki memberikan sebuah pemahaman dalam merelasikan gender yang tereduksi. Hubungan yang merelasi ialah sebuah pemahan tentang seksualitas. Maka muncul perbedaan sex differences dan gender differences yang memberikan sebuah deskriminasi pada perempuan, sehingga perlakuan masyarakat kepada perempuan sangat tidak humanis sehingga tidak keistimewaan femenis lebih rendah daripada patriarki. Perbedaan tersebut memberikan padangan pada sifat femenis dan sifat patriarki sebagai pembeda yang berdasarkan dan merujuk pada seks yang tertanam pada sifat lahiriyyah. Sifat maskulin patriarki digambarkan seperti sensitive, agresif, realistis, body shaming, mempunya gairah tinggi, fisik yang kekar, kuat, sebalik sifat maskulin femenis digambarkan orang yang pasif, jiwa pengasuh, penerima, emosional, dan memiliki tubuh yang lemah. (Kadarusman \& Purwanto, 2005, pp. 3-4)

Streotip gender adalah permasalahan yang sering muncul ditengah masyarakat yang menjadikan sebuah pedang pelarangan kepada anak laki-laki maupun perempuan agar tidak menghilangkan sebuah steotip yang lama berkembang. Streotip inilah yang membuat adanya batasan-batasan kepada laki-laki dan perempuan, misal laki-laki tidak boleh mainan masak-masak karena hal ini tugas seorang perempuan, begitu juga dengan perempuan tidak boleh main bola karena permainan sepak bola adalah permainan laki-laki. Akan tetapi dalam satu dekade terakhir ini hal ini sudah tidak ada pelarang lagi, banyak dari kalangan perempuan yang bisa main bola begitu juga sebaliknya banyak laki-laki yang bisa masak.

Datangnya ide femenis memberikan hal positif tentang kesetaraan tanpa melecehkan gander, sampai akhirnya problem patriarki menjadi netral dan berjalan dengan indah yang memposisikan seorang laki-laki tidak bisa mengaggap hal yang paling berkuasa dalam segala bidang melainkan harus bersikap yang bisa menyetarakan femenis dan patriarki. (N. Umar, Sukri, Institut Agama Islam Negeri (IAIN) Walisongo (Semarang), \& Pusat Studi Jender (PSJ), 2002, pp. 3-4) 
Najwa sihab mengatakan bahwa semua perempuan itu bisa melakukan perkerjaan sebagaimana seorang laki-laki, perempuan yang selama ini hanya bisa melakukan empat hal seperti mens, menyusui, hamil dan mengasuh seakan mereka hanya menjadi perhiasan yang hanya bisa dilihat keindahannya tapi tidak bisa menikmati barang yang lain. Steorip ini seakan melawan pada nalar berpikir manusia, tentang penyetaraan yang tidak berlaku adil kepada feminis. Pada hakikatnya manusia yang tidak mengenal gender manapun itu harus bisa saling bantu menbantu demi mendapatkan keharmonisan dalam berinterkasi, bersosial dan berkomunikasi dengan masyarakat. Saat ini yang dibutuhkan perempuan ialah saling bantu membantu. perempuan bukan untuk direndahkan, dilecehkan dicacimaki, atau bahkan dijatuhkan harga dirinya.

Fenomena pelecehan seksual yang terjadi di kota Surabaya, membuat peneliti berpikir kritis tentang hal tersebut. Karena tindakan seperti ini tidak terpuji dan menganggap bahwa perempuan hanya sebagai pelapias nafsu saja. Dalam kajian femenisme hal ini sangat di kaji betul, sampai cat calling pun itu sudah bentuk pelecehan kepada perempuan. Untuk mengambil kesimpulan dan tidak saling salah menyalahkan maka dalam penelitian ini akan dibasah mengenai perbedaan pola komunikasi femenisme dan patriarki.

Pada penelitian ini menjelaskan tema tentang bagaimana pola komunikasi femenisme dan patriarki untuk lebih spesifik dalam penelitian ini maka mengambil sampel dan objek dari video narasi Najwa Shihab dan Agnes Munica tentang femenisme, untuk membuat penelitian ini lebih spesifik maka dalam permasalahan ini peneliti menarik untuk memaparkan dan mengidentifikasi masalah yang terjadi pada pola komunikasi feminisme yang salama ini tidak terlihat terjadi ada penyetaraan dan adanya kesalahan dalam beranggapan tentang streotip gender. Penelitian ini bertujuan untuk menjelaskan pola komunikasi femenisme yang masyarakat anggap bahwa laki-laki yang harus menjadi pemimpin sedangkan wanita hanya bisa menjadi ibu rumah tangga yang bertugas melayanin suami dan istri. 
COMMUNICATIONS Vol..3(1) 2021, p.87-107

e-ISSN: 2684-8392 |https://doi.org/10.21009/Communications3.1.5

\section{TINJAUAN PUSTAKA}

Untuk memberikan sebuah kebaruan dalam penelitian ini maka peneliti akan memberikan beberapa penelitian terdahulu yang sedikit memiliki kesamaan, agar bisa memberikan sebuah gambaran dalam penelitian ini. Penelitian terdahulu dalam penelitian ini ada diambil 6 dari penelitian jurnal nasional mapun internasional untuk mengukur dan menghindari kesamaa dalam penelitian ini.

Pertama, penelitian ini menunjukkan bahwa ungkapan Ghazala Anwar memberikan paradigma tentang keinginan dan sebuah kebutuhan yang ada pada diri setiap gander itu berbeda, sehingga realita yang terjadi seakan menyalahi dalam memenuhi hak seorang perempuan seperti yang dijelaskan dalam Al-Quran yang dijelaskan dalam berbagai kajian gender dan komunitas gender muslim. Hal ini di ketahui atau tidak oleh kebanyakan perempuan, bahwa laki-laki telah memberikan batasan dan mencuri bahkan merampak hak yang ada pada perempuan, dan perempuan begitu taat kepada laki-laki dengan memberikan hak tersebut secara gamlang karena sebab tidak pahamnya kaum femenisme terhadap penjelasan hak-hak perempuan dalam AlQur'an. Setelah mengetahui hal tersebut datang gerakan baru yang mengajak kepada perempuan untuk memperdalam sebuah teologi tentang hak dan keinginan perempuan. Dengan strategi awal harus menguasai spesifikasi keilmuan yang ada pada laki-laki. (T. M. Umar, 2005)

Kedua, Film "Snow White and the Huntsman" menceritakan feminisme dalam mengambil sebuah keputusan, kekuatan, dan kepemimpinan. Kebebasan perempuan di framing untuk memberikan sebuah kebebasan dalam mengambil sebuah keputusan. film menceritakan bagaimana kekutan yang tertanam dalam diri perempuan misal seperti kekuatan fisik, kecerdasan dalam berpikiran, dan reflektif dalam hal mistis. Dalam memimpin implementasi perempuan juga bisa memberikan persuasif kepada para pengikutnya. Ada satu sisi yang kadang muncul sifat femenismenya, tetapi dibalik itu terdapat sisi yang menentang pada norma dan nilai femenisme itu sendiri. Tokoh perempuan dalam melakukan hal-hal yang berkaitan dengan femenisme dilakukan yang tidak keluar dari internal dan eksternal sifat femenisme, meskipun tidak selalu sama dengan tokoh laki-laki yang kelihatan bisa 
menguasi dalam lingkup pemerintahan ataupun kerajaan, misalnya benda-benda, hewan-hewan dan kurcaci yang terdapat dalam film ini. (Chornelia, 2013)

Ketiga, penelitian ini menggunakan sebuah analisis wacana pada cerpen "Secangkir Kopi Terakhir" karya Li'izzah Nur Diana yang mendapatkan sebuah kesimpulan sebagai berikut, Cerpen 'Secangkir Kopi Terakhir" dalam analisis ini menggunakan kritik lingustik terdapat pesan moral yang mengkisahkan subuah kehidupan dan budaya dalam aktivitas santri di sebuah pondok pesantren yang femous dengan sebuah ketaatan antara santri dan kiyai, dan sebuah ketaatan santri kepada orang tuanya. Dalam cerpen ini memberikan sebuah kritikan tentang implementasikan ketaatan santri yang subur dengan budaya patriarkhi yang menurunkan martabat peran perempuan dalam lingkungan masyarakat. Cerpen ini menceritakan tentang pengalaman yang berada dilingkungan pondok pesantren. Cerpen ini terbentuk karena adanya sebuah perkembangan wacana ada dalam persepsi masyarakat, penulis berlatar belakang yang berasal dari jawa tengah Bantul, sebuah kabupaten di Daerah Istimewa Yogyakarta, kota yang terkenal istimewa terdapat banyak pesantren dengan melting dengan budaya. (Fanaqi, 2019)

Keempat, penelitian ini menunjukkan masalah sosial tentang sebab dan akibat kelanggengan pada budaya dan sreotip patriarki. Feminisme berusaha melawan budaya patriarki yang salah satu penggugat tersebut ialah Raden Ajeng Kartini, sampai saat ini banyak perubahan subtansi, struktur, maupun kultur tentang perjuangan penggugat dari perempuan. Walaupun tidak mudah mengubah problem gender yang terkonstruk tidak setara dan tidak adil kepada gender dan ramah perempuan, akan tetapi tetap dilakukan usaha itu. Penggugatan ini harus diikuti secara simultan dengan advokasi untuk mensupport dengan menjadikan perubahan sikap dan prilaku secara struktural maupun kultural yang adil dalam gender (Sakina \& A., 2017)

Kelima, penelitian ini membahas secara historis seksisme yang belum menjadikan khas dunia Islam atau agama Islam. Yang aneh adalah bahwa kesenjangan yang terlihat telah muncul di zaman modern antara dunia Islam dan Kristen Barat sehubungan dengan tingkat peningkatan egaliter dalam hak-hak perempuan. Kesenjangan ini disebabkan oleh warisan kolonialisme, keterbelakangan, modernisasi 
COMMUNICATIONS Vol..3(1) 2021, p.87-107

e-ISSN: 2684-8392 |https://doi.org/10.21009/Communications3.1.5

yang rusak, kelemahan kelas menengah modern, defisit demokrasi, kegigihan konstruksi patriarki budaya dan agama seperti syariah yang bersumber dari kegagalan reformasi dan sekularisasi di dalam negeri. Islam, dan kelemahan organisasi masyarakat sipil terutama organisasi wanita di dunia Muslim (Tohidi, 2007)

Gelombang baru-baru ini dalam politik identitas, Islamisme, dan gerakan religionasionalis sebagian disebabkan oleh dislokasi sosial-ekonomi dan budaya, polarisasi, dan keterasingan yang disebabkan oleh modernisasi, westernisasi, dan globalisasi, dan sebagian lagi merupakan "gerakan protes patriarkal" sebagai reaksi terhadap tantangan yang muncul dari perempuan kelas menengah modern terhadap hubungan gender patriarki tradisional. Proses demokratisasi, pembangunan masyarakat sipil, dan konsolidasi hak-hak sipil dan hak-hak universal manusia/wanita terkait dengan reformasi dalam Islam, wacana feminis, dan gerakan perempuan. Gender telah menjadi titik buta demokratisasi di dunia Islam. Dalam hal implikasi kebijakan nasional dan internasional, harus diakui bahwa perempuan dan pemuda telah menjadi kekuatan utama modernisasi dan demokratisasi di dunia Islam, terutama di Iran (Tohidi, 2007).

Demokrasi tidak dapat dibangun tanpa generasi baru pemimpin Muslim dan elite negara yang lebih sadar akan realitas baru dunia yang terglobalisasi dan lebih berkomitmen pada hak-hak perempuan/hak asasi manusia universal. Untuk memenangkan perang melawan terorisme dan Islamisme patriarki, kita membutuhkan lebih dari kekuatan militer. Dalam jangka pendek dan menengah, resolusi yang adil dari konflik Israel-Palestina dapat mengubah lingkungan sosial-psikologis saat ini yang memungkinkan tumbuhnya politik ekstremisme dan bias identitas pria; dalam jangka panjang, demokratisasi dan pembangunan yang peka gender tampaknya merupakan satu-satunya strategi yang efektif. Komponen penting dari strategi ini haruslah reformasi Islam, yang membutuhkan dialog internasional dengan dan dukungan untuk suara egaliter dan demokratis yang sekuler dan religius di dunia Muslim (Tohidi, 2007).

Keenam, Berdasarkan temuan penelitian ini, dapat dikatakan bahwa patriarki masih tetap menjadi kenyataan hidup bagi banyak wanita di Malaysia. Konteks patriarki untuk wanita mencakup kehidupan pribadi dan publik mereka dan terus menata 
kehidupan mereka terlepas dari kemajuan mereka dalam bidang-bidang seperti pendidikan dan kesehatan. Ini bukan tugas yang mudah bagi perempuan untuk menantang patriarki, tetapi ini harus dilakukan jika perempuan ingin mencapai potensi penuh mereka dan bercita-cita untuk posisi-posisi yang saat ini didominasi oleh lakilaki (Azmawati, Endut, Hashim, Hafizah, \& Ying, 2017).

Wanita memiliki keyakinan pada kemampuan mereka untuk berkontribusi secara efektif dan dengan cara yang sama seperti pria di berbagai bidang kehidupan mereka seperti pekerjaan, rumah, dan komunitas. Namun, seringkali mereka harus menegosiasikan jalan mereka di sekitar berbagai kepercayaan, praktik, dan norma tentang keunggulan laki-laki di masyarakat. Para wanita memiliki pandangan berbeda tentang bidang-bidang pembagian gender, tenaga kerja dan tentang bagaimana faktor-faktor ini mempengaruhi mereka. Ketika diberikan ruang untuk mempertimbangkan hubungan gender yang lebih adil dengan menciptakan kasus pembalikan peran, perempuan mungkin dapat mengklaim ruang-ruang ini dan berlangganan kemungkinan perubahan norma tentang hubungan antara perempuan dan laki-laki dalam masyarakat. Jika ruang-ruang ini disediakan secara luas untuk perempuan dan laki-laki, patriarki mungkin dapat ditantang lebih efektif (Azmawati et al., 2017).

Ketujuh, penelitian ini membahas tentang perempuan yang Dilema dalam mengembah amanah di sebuah sekolah penelitian ini termasuk menyeimbangkan berbagai peran, menegosiasikan hubungan dengan ketiga pelaku, dan menjaga integritas suara kepala sekolah sambil menceritakan versi kisah diri sendiri tentang kisah kehidupan. Bukan kebetulan bahwa istilah yang serupa keseimbangan, negosiasi, peran, dan hubungan muncul baik ketika penjabaran tentang metode proyek dalam membingkai hasilnya. Metode di pilih secara bersamaan merefleksikan dan memengaruhi kisah yang diceritakan prosesnya sangat dinamis tentang kepsek. Metode dan hasil dalam proyek ini tergantung pada pemahaman tentang kehidupan sosial sebagai pembatas dan diciptakan oleh individu yang membangun makna dan hubungan dalam berbagai konteks. Pemahaman ini membuat kita, sebagai peneliti, menggunakan metode yang memungkinkan kita menemukan dan mempertimbangkan berbagai persepsi tentang realitas dan realitas menyajikan 
COMMUNICATIONS Vol..3(1) 2021, p.87-107

e-ISSN: 2684-8392 |https://doi.org/10.21009/Communications3.1.5

temuan yang mencerminkan kesadaran suara kita sendiri sebagai salah satu dari banyak (Smulyan, 2000).

Tabel 1. Perbanding Penelitian

\begin{tabular}{|c|c|c|c|}
\hline No & Nama Peneliti & Topik Penelitian & Hasil Penelitian \\
\hline 1 & Muthiah Umar & $\begin{array}{l}\text { Propoganda } \\
\text { Femenisme dan } \\
\text { Perubahan sosial }\end{array}$ & $\begin{array}{l}\text { Perbedaan eminism kebutuhan } \\
\text { dan keinginan perempuan dan } \\
\text { laki-laki. }\end{array}$ \\
\hline 2 & $\begin{array}{l}\text { Yolanda Hana } \\
\text { Chornelia }\end{array}$ & $\begin{array}{l}\text { Representasi } \\
\text { feminism dalam film } \\
\text { "snow white and the } \\
\text { huntsman" }\end{array}$ & $\begin{array}{l}\text { Film ini menjelaskan tentang peran } \\
\text { femenisme dalam pengambilan } \\
\text { keputusan, } \\
\text { kepemimpinan dan androgini }\end{array}$ \\
\hline 3 & $\begin{array}{l}\text { Chotijah } \\
\text { Fanaqi }\end{array}$ & $\begin{array}{lr}\text { Kritik } & \text { terhadap } \\
\text { konstruksi } & \text { budaya } \\
\text { patriarki } & \\
\text { Melalui karya sastra }\end{array}$ & $\begin{array}{l}\text { Cerpen secangkir kopi } \\
\text { mereprentasikan ketaatan santri } \\
\text { pada guru, santri pada orang tua. }\end{array}$ \\
\hline 4 & $\begin{array}{l}\text { Ade Irma } \\
\text { Sakina, } \\
\text { Dessy } \\
\text { Hasanah Siti A. }\end{array}$ & $\begin{array}{lr}\text { Menyoroti } & \text { Budaya } \\
\text { Patriarki Di Indonesia }\end{array}$ & $\begin{array}{l}\text { Relasi antara budaya patriarki dan } \\
\text { masalah interkasi sosial serta } \\
\text { realitas sosial yang terjadi pada } \\
\text { masyarakat Indonesia. }\end{array}$ \\
\hline 5 & Nayereh Tohidi & $\begin{array}{l}\text { "Islamic Feminism": } \\
\text { Negotiating } \\
\text { Patriarchy and } \\
\text { Modernity in Iran }\end{array}$ & $\begin{array}{l}\text { Persaingan Gender, rezim jender } \\
\text { di Iran, gerakan perempuan yang } \\
\text { menentangnyar memiliki } \\
\text { kompleksitas, rumitnya negoisasi } \\
\text { perempuan di Iran. }\end{array}$ \\
\hline 6 & $\begin{array}{l}\text { Azman Azwan } \\
\text { Azmawati, } \\
\text { Noraida Endut, } \\
\text { Intan } \\
\text { Hashimah } \\
\text { Mohd Hashim, } \\
\text { Nor Hafizah } \\
\text { Selamat and } \\
\text { Kelvin Ying }\end{array}$ & $\begin{array}{l}\text { Negotiation with } \\
\text { Patriarchy in } \\
\text { Women's Lives: A } \\
\text { Case Study in a } \\
\text { Malaysian Public } \\
\text { University }\end{array}$ & 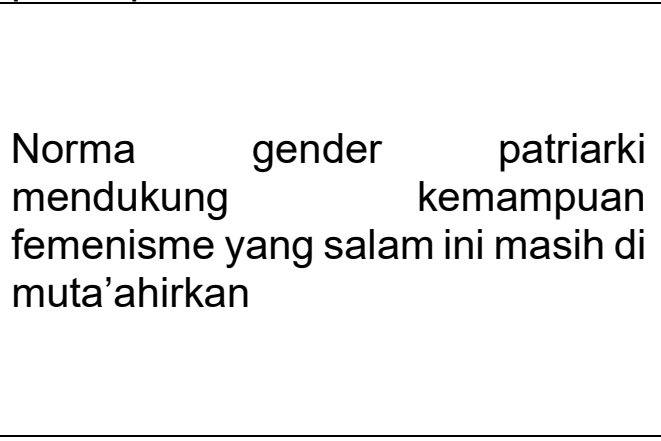 \\
\hline 7 & Lisa Smulyan & $\begin{array}{l}\text { Feminist cases of } \\
\text { nonfeminist subjects: } \\
\text { case studies of } \\
\text { women principals }\end{array}$ & $\begin{array}{l}\text { Diskiminasi pada perempuan } \\
\text { khususnya kepala sekolah dan } \\
\text { pekerja }\end{array}$ \\
\hline 8 & $\begin{array}{l}\text { Muhammad } \\
\text { Munir } \\
\text { Dimas Ayu } \\
\text { Pamukir }\end{array}$ & $\begin{array}{l}\text { Pola komunikasi } \\
\text { feminisme Dalam } \\
\text { Video Najwa Shihab } \\
\text { dan Agnes Monica }\end{array}$ & $\begin{array}{l}\text { 1. } \quad \text { Pola Komunikasi } \\
\text { 2. Perbedaan Gander } \\
\text { 3. Streotip Femenisme } \\
\text { patriarki }\end{array}$ \\
\hline
\end{tabular}




\section{METODOLOGI}

Peneliti menggunakan metode analisis konten yang difokuskan sebuah konten. Metode ini digunakan untuk mereprentasikan sebuah konsep, karakter atau kalimatkalimat yang tersebunyi dan mengandung makna luas. Penelitian ini menggunakan metode pengumpulan data coding pada konten yang dianggap penting pada video narasi Najwa Shihab dan Agnes Monica, yang berjudul Video Narasi TV "Catatan Najwa x Agnes Mo". Video tersebut menceritakan peran, pola komunikasi fenenisme di berbagai tempat sosial. Peneliti melakukan analisis data peneliti yaitu menganalisis, mengeksplorasi data, menampilkan dan memvalidasi data.

\section{HASIL PENELITIAN DAN PEMBAHASAN}

Dalam video Najwa Shihab dan Agnez Mo yang menjadi objek dalam penelitian ini, mereka sepakat membicarakan tentang perempuan harus lebih percaya diri dan saling menguatkan bukan melemahkan. Isu perempuan menjadi salah satu bahasan seru di Catatan Najwa x Agnez Mo. Keduanya berbagi obrolan, tentang problem perempuan yang tak yakin dengan kemampuan diri sendiri dalam bekerja dan meraih cita-cita.

Isu identitas gender menjadi perbincangan mendalam, isu yang diangkat yaitu tentang budaya patriarki yang masih budaya yang kental di Indonesia. Menurut Najwa dalam video narasi tersebut, yaitu:

"Menjadi Indonesia itu bukan karena garis keturunan, tapi karena niat untuk menjadikan negeri ini rumah kita bersama".

Dalam diskusi tentang perempuan di dalam video tersebut, Agnez memberikan sebuah motivasi kepada para mellenial agar menjadi pemuda yang tidak bermental 'instan', harus mau gagal dan konsisten untuk membangun kemampuan dirinya. Proses itu tak mengkhianati hasil, anak muda harus bisa bangkit karena jiwa millenal adalah jiwa membangun 'legacy'-nya.

Pola momunikasi feminisme dan patriarki berpacu pada aksi, interaksi, dan sosialnya, 
COMMUNICATIONS Vol..3(1) 2021, p.87-107

e-ISSN: 2684-8392 |https://doi.org/10.21009/Communications3.1.5

karena dalam sebuah kesuksesan seorang gender di tuntun untuk menjadi pribadi komunikatif dalam melakukan sesuatu, sehingga orang lain dapat mengirim dan menerima gejala dan gangguan yang bisa menggangu perekomonian, yang terjadi pada ruang lingkup tertentu dalam sebuah problem kehidupan, mempunyai daya tarik yang khusus, dan peluang untuk mendapatkan feed back.

Pola komunikasi femenisme dan patriarki dalam behaviorisme terdapat 3 bentuk pola: pola dalam fisik, pola dalam sosial-psikologis, dan pola dalam realita sosial. Pola komunikasi berlangsung dalam sebuah ruang yang disebut sebuah fisik behavioris yang artinya realita dalam sebuah lingkungan, bentuk apa saja, memiliki daya tarik dalam memberikan arti kepada sebuah pesan seperti apa pesan yang disampaikan. (Rokhmansyah, n.d., p. 9)

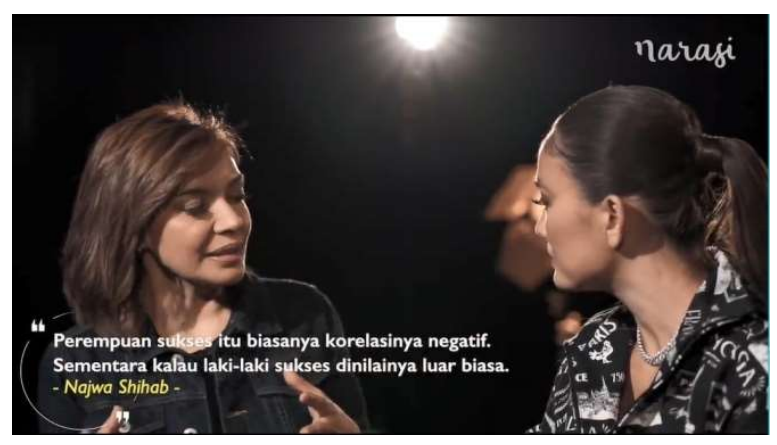

Gambar 2. Adegan tentang pola komunikasi feminisme dan Patriarki Sumber: Video Narasi TV "Catatan Najwa x Agnes Mo"

Shot di atas menjelaskan bahwa dahulu dominasi dalam dunia kerja itu di mayoritaskan oleh laki-laki. Karena sebenarnya perempuan dalam dunia kerja itu lebih empati lebih mendengarkan lewat hati, lebih bersosial dengan orang, tetapi juga ada yang tidak suka dengan women enterpreneur itu tidak bisa mengamil take react, tapi menurut Najwa dan Agnes dalam shot ini bahwa perempuan itu lebih banyak melakukan take react, seperti terbiasa memilih memilah suatu masalah. Dalam pandangan Agnes, juga memberikan contoh kepada ibunya yang sibuk dalam mengurus pekerjaan rumah tangga tapi juga masih bisa mengurus karirnyanya sangat multi tasking. Contoh tersebut ialah salah satu perempuan yang excellent, karena sudah terbiasa taking react, tetapi anak muda zaman sekarang masih belum sadar dan mengetahuinya. 
Perempuan harus melakukan dua kali lipat bahkan lebih dari kekuatan laki-laki. Dalam mengerjakan sesuatu, kalau laki-laki itu bisa hanya dengan dua kekuatan maka perempuan itu harus dengan sepuluh atau lebih untuk mencapai kesamaan dengan laki-laki. Banya anak muda yang belum sadar kalau memiliki potensi yang terpendam khususnya perempuan, mindernya anak muda (perempuan) karena tidak memiliki keyakinan dalam kekuatan diri dan pontensi. Secara tidak sadar merendahkan diri sendiri. Dukungan masyarakat kepada perempuan juga sangat tidak mendukung karena ketika perempuan maju kedepan publik atau massa, perempuan disimbolkan tidak bisa melakukan hal yang sama seperti laki-laki, perempuan itu memang tidak sama akan tetapi perempuan memiliki persepsi bahwa mereka setara.

Dalam kajian femenisme tergolong sebagai kajian yang bersifat sosiologis dan teologis. Menurut perspektif sosiologis kaum femenisme berusaha mendapatkan kesesetaraan gender melalui dekonstruksi yang ada pada sistem patriarki dan rekonstruksi dalam sistem egaliter dalam ruang lingkup tatanan masyarakat. Dalam perspektif teologis memberikan reinterpetasi terhadap narasi agama yang bermuatan sistem patriarki. Penerapan teologi bertujuan untuk membebaskan ketertindasan perempuan yang biasa di kenal dengan theology of feminism yang artinya ialah gerakan reformis dan revolusioner yang mendekonstruksi tentang ideology dan faham tentang agama yang memberikan bias kepada kelelakian. Tujuan dekonstruksi untuk menghapus budaya patriarki, dan menemukan titik kesetaraan gender. Gender ialah bukan sebuah problem sosiologis tapi telah mengalahkan takdir ketuhanan. (Kadarusman \& Purwanto, 2005, p. 35)

Fenomena lainnya adalah adanya sebuah akun yang memberikan ruang gosip kepada para perempuan tentang yang sedang tranding, bukan hal yang aneh di media sosial. Fenomena belakangan ini infortaiment yang tayang di televisi seakan tidak laku dan terganti pada grup gosip di media sosial. Kemenarikan ini justru datang pada perempuan yang sudah nikah atau kita kenal dengan mak-mak, yang biasa bergosip di pasar, tempat belanja dan tempat pertemuan perempuan hal tersebuh seakan tidak menghilang dan mereka lebih memilih untuk bergosip di media sosial saja. (Thornham, 2007, p. 2) 


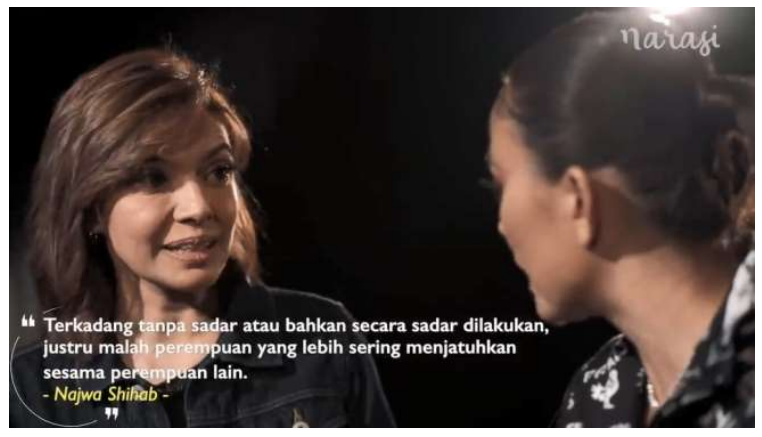

Gambar 3. Adegan tentang pola komunikasi sesama feminisme Sumber: Video Narasi TV “Catatan Najwa x Agnes Mo” Menit 14.45

Shot di atas menjelaskan tentang bullying yang kadang-kadang datang dari sesama perempuan. Hal ini juga tidak cukup dari empowering seorang perempuan dan support dari laki-laki saja, tapi dari motivasi sesama perempuan perlu juga, misal ada seorang perempuan yang sedang tampil di sebuah acara televisi tapi make up yang ia pilih kurang menarik, jadi hal yang harus di support sebagai seorang perempuan ialah mengucapakan kamu so beautiful bukan malah membullynya dengan berbagai katakata yang tidak enak atau malah menjatuhkan diri seorang perempuan.

Seorang perempuan itu tidak hanya putih dikulit saja, tetapi harus bisa baik ketika orang lain menilainya. Dalam keluarga tentang perempuan misalnya gadis yang umur 25 tahun keatas itu dianggap sudah tua dan sangat sulit untuk mendapat jodoh. Shot ini juga menjelaskan tentang komentar orang lain di media sosial kepada kita, sikap kita ialah ambillah komentar dari orang yang terdekat saja bukan dari orang yang tidak dikenal dari kita.

Bullying sebuah aksi kekerasan yang terjadi secara langsung atau maya, bullying tidak hanya kekerasan difisik, tapi juga pada psikologi, mental, cyber. Ancaman ini biasanya terjadi karena tidak mampuan seseorang menyaingi orang lain. Relasi Gender dan seksual bullying sangatlah dekat dan sama-sama memberikan keuntung dan kerugian. Dalam membahas intimidasi gender sebagai aktor yang mempertahankan citra gendernya dalam dominan norma-norma maskulinitas dan feminitas heteroseksual dan intimidasi seksual sebagai intimidasi yang bersifat seksual, Menurut Sullivan 
dalam The Anti-Bullying Handbook menjelaskan perhatian seksual yang tidak diinginkan yang membuat penerima merasa tidak nyaman, rendah diri, atau terhina. Seksual intimidasi berkisar pada tingkat keparahan dari komentar seksual yang tidak diinginkan dan tidak disukai, panggilan-nama, dan menggoda, untuk serangan seksual dan pemerkosaan. (Sullivan, 2011, p. 54)

Praktik patriaki di Indonesia sudah menjadi budaya, budaya tersebut merugikan kebanyakan wanita. Saat ini banyak aktivis feminis dan gerakan menolak patriarki di selenggarakan oleh para aktivisnya demi memberikan sebuah keadilan kepada feminisme di Indonesia. Gerakan tersebut seperti memperjuangkan pada sisi sosial, politik, pekerjaan dan budaya. Masalah sosial yang terjadi di Indonesia seperti terdoktrin oleh kerangka berpikir yang di karang oleh Soetomo. Masalah itu sebenarnya masalah pribadi yang terjadi di lingkungan sosial seperti kekerasan kepada perempuan dalam keluarga, penghinaan kepada seksualitas, meningkatnya nikah dini, dan banyaknya angka perceraian yang menjadi cara terakhir dari permasalahan keluarga. Masalah ini menjadi pendekatan yang memiliki pengaruh kepada streotip patriarki yang menganut system blame approach, akibat sistem tersebut yang menjadi panutan yang salah kepada masyarakat. Maka yang terjadi kepada masyarakat ialah sebuah permalasalah diatas yang terjadi karena sistem budaya patriarki mempunyai kecondongan agar memperoleh sebuah sistem hukum yang bisa mengatasi masalah-masalah tersebut. (Sakina \& A., 2017)

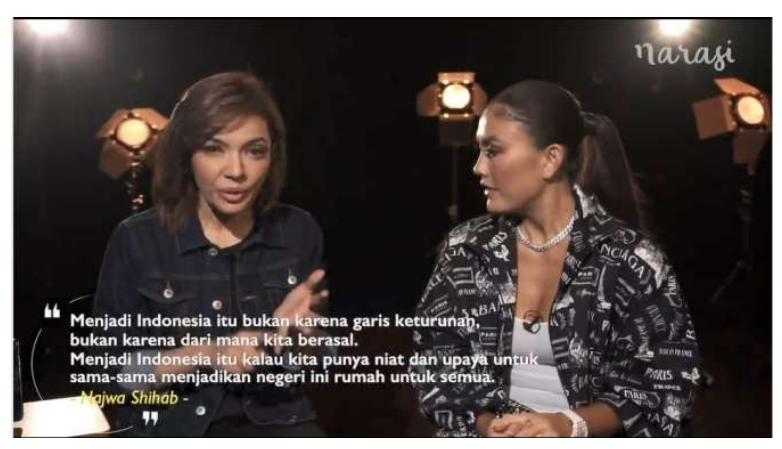

Gambar 4. Adegan tentang garis keturunan di Indonesia Sumber: Video Narasi TV "Catatan Najwa x Agnes Mo"

Shot ini menjelaskan menjadi Indonesia itu tidak harus menurut garis keturunan saja. Permasalah masalah politik, SARA, mayoritas, minoritas, Kristen, Islam, China, Arab 
COMMUNICATIONS Vol..3(1) 2021, p.87-107

e-ISSN: 2684-8392 |https://doi.org/10.21009/Communications3.1.5

dan lain-lain juga harus di jelaskan dan dibicarakan karena semakin di pendam hal ini selalu menjadi bias seperti api dalam sekam, yang dimanfaatkan oleh politik. Bhineka tunggal ika ini adalah slogan kita yang harus kita jaga demi kesatuan dan keharmonisan sebuah bangsa. Apapun garis keturunanya jangan pernahlah membully semua orang yang ada disekeliling atau yang hidup terdekat.

Peran femenisme sangatlah penting untuk meminta keseraan dengan budaya patriarki yang ada di Indonesia khususnya. Lahirnya teori tentang feminisme untuk melawan legitimasi doktin budaya patriarki dari penafsiran yang berasal dari agama. Teori feminis memberikan sebuah kritikan terhadap budaya patriarki yang di kaji melalui pendekatan sosiologi yang di mix keranah teologis. Gerakan aktivis teologis yang ada di Amerika Serikat dengan memberikan argumentasi kepada kaum feminis untuk mengadopsi paradigma Marxis, teologi tersebut telah sukses menghantarkan sebuah revolusi fundamental. (Kadarusman \& Purwanto, 2005, p. 31)

Dalam pandangan feminisme barat yang memposisikan laki-laki sebagai kepala keluarga yang bisa mengatur perempuan hal ini menjadi budaya dan bahkan kewajiban yang harus di penuhi oleh perempuan, akibat simbol patriarki yang memegang kekuasaan terjadilah sebuah diskriminasi pada perempuan. Dalam banyak kasus tentang perempuan di berbagai belahan dunia setelah menikah melucuti dan menyalah artikan kewajiban setelah melakukan pernikahan, bahkan kebanyakan perempuan tunduk apapun kemauan lelaki, dengan landasan untuk menganti kerugian yang dipakai dalam acara pernikahan before and after padahal sedikit tetapi mereka menuntuk keadilan dari wanita. (Said, 2005, p. 54)

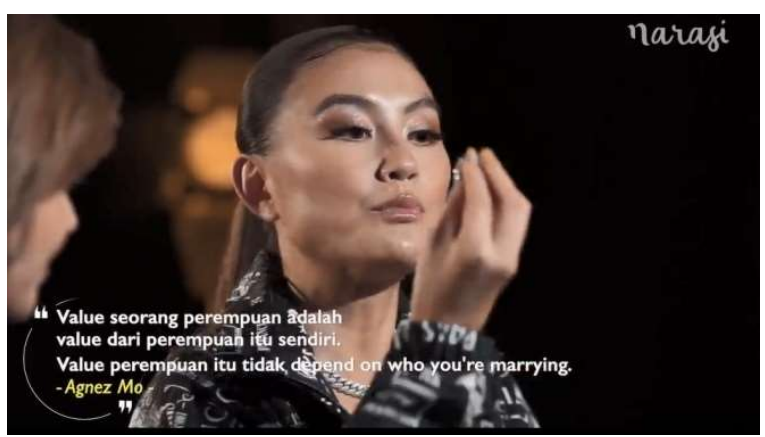

Gambar 5. Adegan tentang nilai seorang perempuan Sumber: Video Narasi TV "Catatan Najwa x Agnes Mo" 
Shot di atas menjelaskan tentang peran perempuan didalam keluarga yang selalu menekankan untuk menikah. Karakter seorang perempuan itu berbeda dan tidak selamanya sama. Menurut Agnes sepertinya tujuan perempuan itu hanya tidak menikah dengan laki-laki. Dalam memelihara rasa aman dalam hidup seorang perempuan dengan membentuk mental yang percaya diri, bagaimana kita mempersepsikan diri atau bagaimana kita menilai fenomena-fenomena yang terjadi dalam hidup. Karena nilai dan potensi seorang perempuan itu ditentukan oleh perempuan itu sendiri, bukan ditentukan orang lain baik itu keluarga maupun sahabat. Menurut pendekatan epistemologi femenisme sosialis ialah pemahaman tentang penindasan kepada perempuan dan semua bukti pengetahuannya di implementasikan kepada kepentingan tertentu dalam kelompok sosial. Deskripsi yang bervariasi tentang historis dalam teoritik ataupun praktek tentang pemahaman yang dinilai. Teori epistemology memberikan paham bahwa laki-laki memiliki material tertentu dari perempuan dan konstruksi laki-laki merupakan institusional dalam melanggengkan. (Kadarusman \& Purwanto, 2005, p. 30)

Penindasan bersifat spesifik karena yang mengetahui problem yang ada di dalam diri baik privet maupun publik, bahkan penindasan yang terjadi kepada perempuan lebih banyak dari pada laki-laki. Dalam sebuah ungkapan fisik perempuan itu ialah ladang atau area perang. Penindasan tersebut terjadi karena faktor kecantikan atau body shaming yang terkonstruk sebagai alat pemuas, seks hingga alat barter karena kepemilikan itu sepenuhnya dari kekuasaan laki-laki. Dengan artian tubuh perempuan sebagai target pemuas bagi laki-laki saja. Estetika fisik perempuan dijinakan, dikurung, dan skillnya hanya berpotensi sebagai pekerjaan reproduksi, jasa, dan penjagaan.

Potensi dalam diri perempuan terkonstruk hanya diberikan untuk domestik lelaki, dalam hal ini perempuan hanya bisa tinggal dirumah melakukan hal-hal rumah tangga seperti mengasuh anak, melayani suami dan lain-lain. Dalam pengalaman privet atau publik perempuan mengalami sebuah penindasan, seperti: perlakuan kasar dan tidak manusiawi, membatasi peran perempuan, stereotip, dikomodifikasi, double job, sebagai pemuas nafsu, dan sebagai korban feminisasi kemiskinan. (Nasution \& Simanjuntak, 2016, p. 20) 


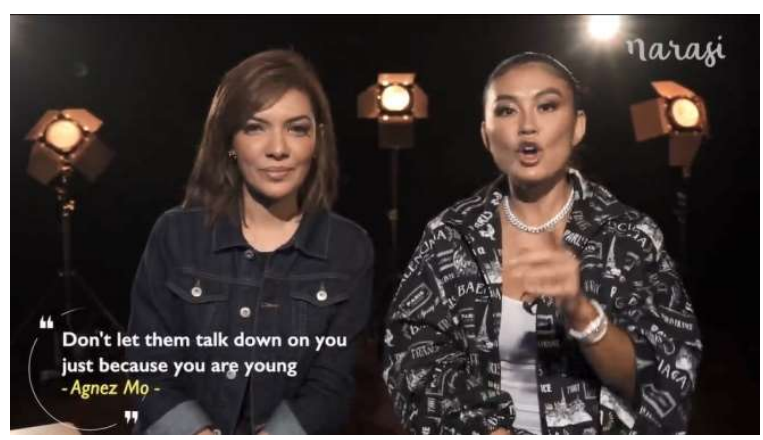

Gambar 6. Adegan tentang garis bahwa perempuan itu tidak lemah Sumber: Video Narasi TV “Catatan Najwa x Agnes Mo” menit: 42.58

Shot di atas menjelaskan tentang jiwa muda itu tidak harus down ketika mendapatkan masukan dari orang lain yang mengatakan kita masih dan tidak tahu apa-apa. Karena pemudalah yang memiliki energi dan bisa mengubah segalanya seperti millennial feminism dan millennial patriarchy.

Menurut aliran Marxis, penindasan pada perempuan itu sepenuhnya bukan karena faktor tindakan individu secara sengaja, tetapi dari konstruksi politik, sosial, dan ekonomi yang ada dalam sistem kapitalisme. Dalam aliran ini memberikan keimanan bahwa sistem kapitalisme telah membuat perempuan dianggap tidak setara. Pandangan dalam argumentasi Marxis berdasarkan problem yang terjadi dalam ketidak adilan di dunia pekerjaan dan status kepemilikan bahwkan kepermimpinan. (Kadarusman \& Purwanto, 2005, p. 31)

\section{KESIMPULAN}

Pola Komunikasi Feminisme dan Patriarki dalam Dunia Kerja adalah setara bukan sama. Femenisme juga bisa mengerjakan apa yang bisa dikerjakan oleh laki-laki tetapi dengan kekuatan yang harus di atas laki-laki, jika laki-laki menggunakan kekuatan dua maka femenisme itu harus sepuluh atau lebih untuk menyetarakan hal tersebut. Dalam hal ini masyarakat harus mendukung kepada perempuan ketika perempuan maju kedepan publik atau massa, perempuan disimbolkan tidak bisa melakukan hal yang sama seperti laki-laki, perempuan itu memang tidak sama akan tetapi perempuan 
memiliki persepsi bahwa mereka setara.

Pola komunikasi sesama femenisme ialah tidak membully ketika perempuan itu tidak berada dalam sifat yang sebagaimana layaknya perempuan tetapi di semangati. Bhineka Tunggal Ika adalah slogan bangsa Indonesia yang menandakan bahwa Indonesia memiliki banyak kultur, banyak agama, banyak perbedaan-perbedaan yang mungkin belum terlihat. Budaya patriarki yang ada pada budaya Indonesia, bukan untuk saling menjatuhkan, saling menindas, saling mengakui keperkasaan sendiri tetapi perbedaan itu untuk menjadikan Indonesia rumah kita bersama yang aman dan adil.

Peran Femenisme Dalam Pernikahan ditandai dengan streotip orang tua yang menganggap bahwa wanita karir belum terlalu penting. Karakter seorang perempuan itu berbeda dan tidak selamanya sama. Perempuan lahir bukan untuk diciptakan sebagai pemuas dan dan hanya untuk menikah. Hadirnya Millennial feminism dan millennial patriarchy diharapkan dapat menjadi energi bangsa yang bisa merubah bangsa ke bangsa yang lebih maju. Pemikiran anak muda bukan untuk direndahkan tapi ditampung sebagai aspirasi.

\section{REFERENSI}

Azmawati, A. A., Endut, N., Hashim, I. H. M., Hafizah, N., \& Ying, K. (2017). Negotiation with Patriarchy in Women's Lives: A Case Study in a Malaysian Public University. 9.

Chornelia, Y. H. (2013). Representasi Feminisme Dalam Film. 12.

Dzuhayatin, S. R., Rachman, B. M., \& Umar, N. (2002). Rekonstruksi metodologis wacana kesetaraan gender dalam Islam (Cet. 1). Yogyakarta: PSW IAIN Sunan Kalijaga.

Fanaqi, C. (2019). Kritik Terhadap Konstruksi Budaya Patriarki Melalui Karya Sastra. $5(2), 13$.

Ihromi, T. O., Irianto, S., \& Luhulima, A. S. (Eds.). (2000). Penghapusan diskriminasi terhadap wanita $\left(1^{\text {st }}\right.$ ed). Bandung: Penerbit Alumni.

Ismail, N. (2003). Perempuan dalam Pasungan bias Laki-laki dalam penafsiran (1 ${ }^{\text {st }}$ ed). Bantul, Yogyakarta: LKiS Yogyakarta. 
Jamhari (Ed.). (2003). Citra perempuan Islam: Pandangan ormas keagamaan. Jakarta: Gramedia Pustaka Utama bekerjasama dengan PPIM-UIN dan the Ford Foundation.

Kadarusman, \& Purwanto, H. (2005). Agama, relasi gender \& feminisme. Yogyakarta: Kreasi Wacana.

Karim, K. A., Nahdiyyin, K., \& Maryam, S. (2007). Relasi gender pada masa Muhammad \& Khulafaurrasyidin. Yogyakarta: Pustaka Pelajar.

Nasution, R., \& Simanjuntak, B. A. (2016). Ketertindasan perempuan dalam tradisi kawin anom: Subaltern perempuan pada suku Banjar dalam perspektif poskolonial ( $1^{\text {st }}$ ed). Jakarta: Yayasan Pustaka Obor Indonesia.

Rokhmansyah, A. (n.d.). Pengantar Gender dan Feminisme: Pemahaman Awal Kritik Sastra Feminisme. Yogyakarta: Garudhawaca.

Said, N. (2005). Perempuan dalam himpitan teologi dan HAM di Indonesia ( $1^{\text {st }}$ ed). Yogyakarta: Pilar Media.

Sakina, A. I., \& A., D. H. S. (2017). Menyoroti Budaya Patriarki Di Indonesia. Share : Social Work Journal, 7(1), 71. https://doi.org/10.24198/share.v7i1.13820

Smulyan, L. (2000). Feminist cases of nonfeminist subjects: Case studies of women principals. International Journal of Qualitative Studies in Education, 13(6), 589609. https://doi.org/10.1080/09518390050211538

Sullivan, K. (2011). The Anti-Bullying Handbook. https://doi.org/10.4135/9781446289006

Thornham, S. (2007). Women, feminism and media. Edinburgh: Edinburgh University Press.

Tohidi, N. (2007). "Islamic Feminism": Negotiating Patriarchy and Modernity in Iran. In I. M. Abu-Rabi'zz The Blackwell Companion to Contemporary Islamic Thought (624-643). https://doi.org/10.1002/9780470996188.ch36

Tong, R. (1997). Feminist thought: A comprehensive introduction (Reprint). London: Routledge.

Umar, N., Sukri, S. S., Institut Agama Islam Negeri (IAIN) Walisongo (Semarang), \& Pusat Studi Jender (PSJ). (2002). Bias jender dalam pemahaman Islam.. Jil. 1 Jil. 1. Yogyakarta; [Semarang: Gama Media ; Pusat Studi Jender (PSJ), Institut Agama Islam Negeri (IAIN) Walisongo.

Umar, T. M. (2005). Propaganda Feminisme dan Perubahan Sosial. Mediator: Jurnal Komunikasi, 6(2), 205-214. https://doi.org/10.29313/mediator.v6i2.1189 